\title{
SHIFTING THE FOCUS OF PROFESSIONAL DEVELOPMENT: FROM INDIVIDUAL TEACHERS' COMPETENCES TO A SYSTEM OF CONTEXTUAL PROFESSIONAL ACTIVITY
}

\author{
Līva Goba-Medne \\ University of Latvia, Latvia
}

\begin{abstract}
The aim of the proposed article is to compare two conceptually different views on teacher professional development: the traditional competence approach and the model of system of contextual professional activity as proposed by the researchers of cultural-historical activity theory. The competence model is aimed primarily at the all-round development of an individual, while the activity system model analyses the actual occurring professional activity in its systemic context. While the competence model helps identify the areas of professional development for an individual teacher, the activity system model lets systemic contradictions in the working practice be identified, analysed and addressed by modelling solutions. In addition, the competencies of individual teachers of an activity system (comprising the teaching-learning process in a particular school) may be considered interconnected and complementary.

It is concluded that the competence approach is more suitable for teacher training and the identification of the required competence spectrum to implement a certain type of curriculum, whilst activity systems approach is suitable for planning and implementing professional development as an effort to redesign work collaboratively on a school level, focusing on the improvement of work practices according to the identified issues, constraints, contradictions and collaboration opportunities.
\end{abstract}

Keywords: Professional development of teachers, Activity systems approach, Competence approach.

\section{Introduction}

Teacher quality and teaching quality have been stated as key assets for the quality building of an education system (European Commission, 2013; Guerriero, 2017). Therefore, teacher professional development, commonly understood as the improvement of the professional competencies of inservice teachers via participation in dedicated activities, is inevitably a focal point in a comprehensive education policy. If initial teacher 
education providers may regard their client to some extent as a blank page (professional identity still to be formed), in the case of organizing professional development of in-service teachers it is crucial to account for the systemic historical developments that shape the common sphere of comprehension. Experience is constructed contextually and so is learning (Goba, 2019). In a country like Latvia with a population of schoolteachers characterised by a high average age and a small proportion of young teachers (Ministry of Education and Science of the Republic of Latvia, 2019), the challenges faced by most teachers during their professional career should be taken into account - such as reorganization of the education system after the collapse of the USSR, democratization, liberalization, significant decrease in teachers' authority in society, changes in the general perception of what pedagogical approaches are to be considered optimal, uncertainty associated to major changes in society (Andersone, 2015; Kokare, 2011; Zaḷaiskalne, 2013).

A new challenge to the schoolteachers of Latvia is the anticipated reform, Skola 2030, that aims at fundamentally shifting the teaching practices (Olina et al., 2018; Skola 2030, 2017). It also sets forth a challenge to reduce teaching-by-example and drilling, shifting the emphasis to fostering critical thinking and deep learning; enhancing skills in curriculum development as well as abandoning the former exemplar curriculums. This reform could set the cornerstone for systemic changes and invigorate learning, but it could also become another trial for the educators to endure before they revert to former practices.

Professional development activities are typically aimed at the competence building of teachers; in Latvia these activities commonly consist of further education courses, education conferences and seminars, as well as observation visits to other schools and organizations (Organisation for Economic Co-operation and Development [OECD], 2019a). The activities are targeted at individual teachers rather than teacher-teams and are mostly disconnected from classroom practices and the specific teaching context. The existent regulatory framework promotes participation in activities that result in a certificate attesting the number of hours devoted to development; ensuring that participation in professional development activities results in positive contributions to the teaching practices is the collaborative responsibility of teachers and school leaders (Kozlovska, 2015).

However, institutionally provided activities have a limited power to influence the practice as there are no universal incentives for teachers to apply the mastered skills and competences in practice, and the evaluation of the impact of certain professional development activities is considered complicated and costly (McChesney \& Aldridge, 2019). Despite the best efforts of policy makers to re-shape the teaching practices, large educational 
reforms are seen to have limited influence over practices and cultures in schools (Labaree, 2012). There are systemic constraints that need to be addressed in order to implement an innovative learning culture as a schoolwide phenomenon in contrast to confined efforts of enterprising individuals. The approach of systems analysis arises as an attempt to overcome these constraints via identifying, analysing and mitigating them (Barab et al., 2002; Engeström, 2001; Yamagata-Lynch \& Haudenschild, 2009).

The aim of the proposed article is to compare two conceptually different views on teacher professional development: the dominating professional competence approach (European Commission, 2013; Pellegrino, 2017) and the systems model of contextual professional activity as proposed by the researchers of cultural-historical activity theory (Engeström, 1987; Engeström \& Sannino, 2010).

\section{Competence approach: typically focusing on an individual}

The historical model of workplace training in business and industry was shaped by the assumption that issues in employees work are caused primarily by deficits of knowledge or skills, therefore targeted programmes are delivered that would alleviate this deficit (Cranton, 1996). Through the years complex competence models have been developed in order to map all the contents of specific competences in detail for optimal performance. Typically arranged through sets of knowledge, skills and dispositions or attitudes (European Commission, 2013), these models help set goals for vocational education curriculums and professional higher education programmes. They are also used to set professional standards and to determine appropriate candidates for certain positions. However, the downside of these elaborate competence models emerges when it comes to their application outside the context of formal education, and professional development of in-service teachers in particular. In fact, the accompanying life-long learning ideology has been criticized for its narrow, utilitarian and instrumental view of learning, prioritizing the needs of the market and diminishing the value of curiosity, emancipation and moral dimension that has been a strong aspect of adult education tradition (Thompson, 2007). The issue with the ponderous competency models has been addressed with new frameworks that emphasize the transversal aspects - such as the $21^{\text {st }}$ century competences (Voogt \& Roblin, 2012), key competences (European Commission, Directorate-General for Education, Youth, Sport and Culture, 2007, 2019), transversal attitudes, skills and knowledge for democracy (Mompoint-Gaillard \& Lázár, 2015).

When it comes to the identification of professional development needs and goals of in-service teachers, how helpful are these competence 
frameworks? If the learning needs are identified as deficits in specific instrumental knowledge and skills, narrowly targeted training should solve the problem. However, large-scale international studies show that collaborative and school-based approaches are among the most impactful types of professional development (OECD, 2019b). The thematic working group on teacher professional development set up by the European Commission points out that due to the complexity and range of competencies required for contemporary teaching, an individual teacher may not be expected to have them all developed to the same high degree, or even developed at all. Therefore, the focus of competence development necessarily shifts towards a teacher team, a school or an entire education system, so that the competence set is embodied collaboratively (European Commission, 2013).

A large body of research shows that the teacher collective efficacy and the beliefs teachers hold about teaching and learning significantly influence student learning (Donohoo, Hattie, \& Eells, 2018; Hattie \& Zierer, 2018). Thus, teacher professional development should be regarded as a process of not only acquiring the lacking knowledge and skills, but also of revising beliefs about education that shape one's dispositions. What we do is shaped by our beliefs, these beliefs are shaped by our experiences and our experiences are inevitably constructed within our life-worlds, shaping our sphere of comprehension (Goba, 2019). Therefore, professional development of in-service teachers necessarily calls for a systemic view.

\section{Activity systems approach: professional development and learning as a school-wide phenomenon}

A greater collaboration and collective learning for the development of teaching profession was encouraged by the OECD publication as early as 2011 as an approach that enhances the professional activity of teaching (OECD, 2011). It is stated that collaborative learning and change efforts need to be supported (OECD, 2016). Teaching is an activity that is explicitly social, intersubjective and contextual. Therefore, it calls for a systemic view of professional activity considering its context, interrelations and contradictory aspects.

The activity systems model developed by Yrjö Engeström offers such a systemic view on professional activity development (Engeström, 1987). Rooted in cultural-historical activity theory (CHAT) (Engeström, 2009), it takes activity system as its initial unit of analysis comprising of the mediated action between subject (teacher(s) engaged in the activity) and object of activity (the horizon of opportunities at which the activity is directed, the carrier of motive of activity), this mediation is realized through cultural 
tools (physical objects as well as concepts, models, signs, languages etc.) and turned into actual outcomes. The described system becomes contextual and descriptive of organizational realities through integrating the systemic elements of community (in which the activity is situated), division of labour (allocation of tasks as well as power and status) and rules that guide and constrain the actions within the system (norms, standards, regulations as well as implicit norms and habitual expectations). Any activity system may be seen as involved in network relations to other activity systems (Engeström \& Sannino, 2010); thus, several interconnected activity systems become the focus of analysis.

If applied to professional development of teachers, this model helps identify contradictions in work practice that may be connected to systemic flaws in work arrangements that alternatively might misleadingly be described as deficiencies in a certain type of competence (YamagataLynch \& Haudenschild, 2009), thereby combining both bottom-up and top-down perspectives. For example, if training is targeted at conflict resolution and communication skills in a situation where conflicts are resulting from ambiguous allocation of tasks and conflicting rules guiding the working practice, the problem might be toned down but not solved. Of course, professional development targeted at individual teachers is less complicated and consumes less resources than analysing and redesigning a whole professional activity within a teacher team or a school. As researchers have noted, there are systemic constraints to collaborative self-organizing learning in schools that systemically inhibit expansive learning - teaching professionals typically work as isolated practitioners in autonomous classrooms; they work in standardised time sequences at schools that function as encapsulated units, while the measured outcome of the activity is expressed in grades (Engeström, Engeström, \& Suntio, 2002). Tensions and contradictions are inevitably encountered when attempting collaborative learning and activity analysis. According to CHAT, contradictions are the driving force of change, therefore the manifestations of contradictions, tensions, ruptures in the flow of activity and double binds are met as learning opportunities (Engeström \& Sannino, 2010).

The activity systems model may be used by coordinators of professional development as an analytic tool to identify systemic contradictions in the working practice and to delineate developmental needs. But it also serves as a conceptual tool for CHAT-based formative interventions that aim at collaboratively developing working practices in a targeted and orderly manner, while developing novel solutions rather than implementing a standardized pre-set scenario developed by an outside expert. The Change laboratory, a method developed by researchers of Helsinki University, serves both for developing working practices (and that necessarily involves 
learning on the part of the involved parties), researching the involved collaborative learning processes and developing the underlying theory of expansive learning (Virkkunen \& Newnham, 2013). Research shows that various aspects influence the progress of the intervention and that, while not guaranteed due to the open-ended nature of the process, the potential gains from the intervention involve: (a) a deeper understanding about the multi-voicedness of the activity gained through analysis; (b) analysis of core concepts involved in the activity provide grounds for negotiation and a better understanding among participants; (c) agency gained by the participants seen as their ability and readiness to engage in reshaping the activity system in question; (d) the reshaped activity system that better serves the needs of those involved (Engeström \& Sannino, 2010; Virkkunen \& Newnham, 2013).

The activity systems approach clearly does not prioritize an all-round development of individuals; neither does it provide an ideal state descriptor. Rather, it is a tool for realistically inquiring into the complex components of social reality. The activity systems approach is an opportunity to create solutions that are not yet there (Engeström \& Sannino, 2010) and to analyse the actual occurring professional activity in its systemic and historical context. From a systemic view, the competencies of individual teachers of an activity system (comprising the teaching-learning process at a particular school) may be considered interconnected and complementary.

\section{Conclusion and discussion}

Two conceptually different views on teacher professional development were analysed in this article: the competence approach and the activity systems approach. Both have extensive research traditions as well as practical applications; however, the systems approach is notably less common in professional development practice among schoolteachers. In Latvia, clearly the dominant approach is directed towards the competence development of individual teachers, disregarding the benefits of other collaborative and school-based forms of professional development (Kozlovska, 2015, OECD, 2019a). However, voices gain power in both European (European Commission, 2013) and global arena (Donohoo et al., 2018; Guerriero, 2017; OECD, 2011, 2019b) that advocate for more consideration of schoolbased realities, learning-collaboration benefits and, consequently, for more systemic approaches to the professional development of teachers. As noted previously, certain systemic constraints distinguish the working practice of teachers that confine collaborative learning and development efforts. Therefore, the systemic dimension of teacher professional development requires special attention. 
The dominating competence approach is more directed at an all-round development of individual teachers and serves as an ideal state descriptor. However, it must be kept in mind that the majority of teachers have not developed all the competencies equally well. The competence approach leads the way for teacher preparation, curriculum design and the identification of learning needs of an individual teacher, but it lacks the descriptive power to tackle systemic problems encountered in the working practice of schools.

The activity systems approach, by contrast, is suitable for planning and implementing professional development as an effort to redesign work collaboratively on a school level (and beyond), focusing on the improvement of work practices according to the identified issues, constraints, contradictions and collaboration opportunities. The activity systems model focuses on the actual occurring professional activity in its systemic context, characterised by the involved actors and other elements of the system. Its strength is the developmental path towards innovating and developing a working practice where a unified and easily transferable solution does not exist.

It may be concluded that both approaches analysed are not fundamentally contradictory: they are two facets of the same reality, each setting the focus differently. A systemic view towards the working practice is necessary to facilitate the transformation of practices and to encourage expansive learning, while the focus on individual dimension allows to account for individual learning needs of teachers and identify teacher beliefs and dispositions that might hinder growth. Being aware of the two discussed approaches capacitates teacher educators and stakeholders to distinguish the means for achieving systemic changes in teaching practices within schools, considering that not all lies within the reach of an individual teacher; collaborative and school-based strategies should be considered.

\section{References}

Andersone, R. (2015). Curriculum for school democratisation: Experience of Latvia. In Z. Rubene (Eds.), Democratization of Education (pp. 10-19). Riga: University of Latvia.

Barab, S. A., Barnett, M., Yamagata-lynch, L., Squire, K., Barab, S. A., Barnett, M., ... Keating, T. (2002). Using activity theory to understand the systemic tensions characterizing a technology-rich introductory astronomy course. Mind, Culture, and Activity, 9(2), 76-107. https://doi.org/10.1207/S15327884MCA0902.

Cranton, P. (1996). Professional development as transformative learning: New perspectives for teachers of adults. Jossey-Bass Publishers.

Donohoo, J., Hattie, J., \& Eells, R. (2018). The power of collective efficacy. Educational Leadership, 75(6), 40-44. https://doi.org/10.1109/TMAG.2009.2012667.

Engeström, Y. (1987). Learning by expanding: An activity-theoretical approach to developmental research. Helsinki: Orienta-Konsultit. 
Engeström, Y. (2001). Expansive learning at work: Toward an activity theoretical reconceptualization. Journal of Education and Work, 14(1), 133-156. https://doi. org/10.1080/13639080020028747.

Engeström, Y. (2009). Expansive learning: Toward an activity-theoretical reconceptualization. In K. Illeris (Eds.), Contemporary Theories of Learning: Learning Theorists in Their Own Words (pp. 53-73). New York: Routledge.

Engeström, Y., Engeström, R., \& Suntio, A. (2002). Can a school community learn to master its own future? An activity-theoretical study of expansive learning among middle school teachers. In G. Wells \& G. Claxton (Eds.), Learning for life in the $21^{\text {st }}$ century: Sociocultural perspectives on the future of education (pp. 211-224). London: Blackwell. https://doi.org/10.1002/9780470753545.ch16.

Engeström, Y., \& Sannino, A. (2010). Studies of expansive learning: Foundations, findings and future challenges. Educational Research Review, 5(1), 1-24.

European Commission. (2013). Supporting teacher competence development for better learning outcomes. Retrieved from https://ec.europa.eu/assets/eac/education/ experts-groups/2011-2013/teacher/teachercomp_en.pdf.

European Commission, Directorate-General for Education, Youth, Sport and Culture. (2007). Key competencies for lifelong learning - European reference framework. Luxembourg: Office for Official Publications of the European Communities. Retrieved from https:// publications.europa.eu/s/mNoq.

European Commission, Directorate-General for Education, Youth, Sport and Culture. (2019). Key competences for lifelong learning. Luxembourg: Publications Office of the European Union. https://doi.org/10.2766/569540.

Goba, L. (2019). Theorizing the concept of transformative learning experience in the context of teacher professional development. Society. Integration. Education. Proceedings of the International Scientific Conference, 5, 119-130. https://doi. org/10.17770/sie2019vol5.3754.

Guerriero, S. (Eds.). (2017). Pedagogical knowledge and the changing nature of the teaching profession. Paris: OECD Publishing. https://doi.org/10.1787/9789264270695-en.

Hattie, J., \& Zierer, K. (2018). 10 mindframes for visible learning: Teaching for success. Milton: Routledge.

Kokare, M. (2011). Mācišanās organizācijā kā pedagogískā procesa perspektīva [Organizational learning as a perspective of pedagogical process] (Doctoral dissertation, University of Latvia). Retrieved from https://luis.lu.lv/pls/pub/luj. fprnt?l = 1\&fn = F1641759629/Maija Kokare 2011.pdf.

Kozlovska, A. (2015). Factors influencing teacher professional development. In A. Geske (Eds.), Teachers in Latvia and around the world (6th ed., pp. 115-148). Riga: University of Latvia Faculty of Education, Psychology and Art Institute for Educational Research.

Labaree, D. F. (2012). School syndrome: Understanding the USA's magical belief that schooling can somehow improve society, promote access, and preserve advantage. Journal of Curriculum Studies, 44(2), 143-163. https://doi.org/10.1080/00220272.201 2.675358 .

McChesney, K., \& Aldridge, J. M. (2019). A review of practitioner-led evaluation of teacher professional development. Professional Development in Education, 45(2), 307-324. https://doi.org/10.1080/19415257.2018.1452782.

Ministry of Education and Science of the Republic of Latvia. (2019). Pedagogu skaits vispārizglìtojošajās dienas skolās. Oficiālā statistika par vispārējo izglītību 
2018./2019. m. g. [Number of teachers in general education day schools. Official statistics on general education in 2018/2019]. Retrieved 7 July 2019, from https:// $\mathrm{izm}$. gov.lv/lv/publikacijas-un-statistika/statistika-par-izglitibu/statistika-parvisparejo-izglitibu/2018-2019-m-g3.

Mompoint-Gaillard, P., \& Lázár, I. (2015). TASKs for democracy - 60 activities to learn and assess transversal attitudes, skills and knowledge. (J. Huber, Ed.). Strasbourg: Council of Europe Publishing. Retrieved from https://book.coe.int/en/pestalozzi-series/6688tasks-for-democracy-pestalozzi-series-no-4.html.

OECD. (2011). Building a high-quality teaching profession: Lessons from around the world. (A. Schleicher, Ed.). Paris: OECD Publishing. https://doi.org/10.1787/9789264113046-en.

OECD. (2016). Teaching excellence through professional learning and policy reform: Lessons from around the world. International summit on the teaching profession. (A. Schleicher, Ed.). Paris: OECD Publishing.

OECD. (2019a). TALIS 2018 Country Notes: Latvia. Paris: OECD Publishing. Retrieved from http://www.oecd.org/education/talis/talis-2018-country-notes.htm.

OECD. (2019b). TALIS 2018 results (Volume I): Teachers and school leaders as lifelong learners. Paris: OECD Publishing. https://doi.org/10.1787/1d0bc92a-en.

Olina, Z., Namsone, D., France, I., Dudareva, I., Čakāne, L., Pestovs, P., ... Butkēviča, A. (2018). Mācīšanās lietpratỉbai. Kolektīva monogrāfija [Learning to gain competence. Collective monograph]. (D. Namsone, Ed.). Rīga: LU Akadēmiskais apgāds. https://doi. org $/ 10.22364 / \mathrm{ml} .2018$.

Pellegrino, J. W. (2017). Teaching, learning and assessing $21^{\text {st }}$ century skills. In S. Guerriero (Eds.), Pedagogical knowledge and the changing nature of the teaching profession (pp. 223-251). Paris: OECD Publishing. https://doi.org/10.1787/9789264270695-en.

Skola 2030. (2017). Izglītiba mūsdienigai lietpratibai: mācību satura un pieejas apraksts [Education for modern competence: Description of study content and approach]. Riga. Retrieved from https://www.skola2030.lv/apspriesana.

Thompson, J. (2007). The road to hell.... In B. Connolly, T. Fleming, D. McCormack, \& A. Ryan (Eds.), Radical learning for liberation 2 (pp. 37-56). Maynooth: MACE.

Virkkunen, J., \& Newnham, D. S. (2013). The change laboratory: A tool for collaborative development of work and education. Rotterdam: Sense Publishers.

Voogt, J., \& Roblin, N. P. (2012). A comparative analysis of international frameworks for $21^{\text {st }}$ century competences: Implications for national curriculum policies. Journal of Curriculum Studies, 44(3), 299-321. https://doi.org/10.1080/00220272.2012.668938.

Yamagata-Lynch, L. C., \& Haudenschild, M. T. (2009). Using activity systems analysis to identify inner contradictions in teacher professional development. Teaching and Teacher Education, 25(3), 507-517. https://doi.org/10.1016/j.tate.2008.09.014.

Zalaiskalne, A. (2013). Structural reforms and changes in compulsory content of vocational education in the Republic of Latvia from 1991 till 2011. In A. Kangro (Eds.), Scientific Papers, University of Latvia: Education Management (Vol. 792, pp. 124-137). Rīga: Latvijas Universitātes Akadēmiskais apgāds. Retrieved from https://www.lu.lv/ fileadmin/user_upload/lu_portal/apgads/PDF/LUR-792_Izglit-vad.pdf. 